\title{
BODY GROWTH AND AGE DETERMINATION OF THE SABLE HIPPOTRAGUS NIGER NIGER (HARRIS, 1838)
}

\section{J. H. GROBLER}

Department of Research and Information

National Parks Board of Trustees

Private Bag X66

Cradock

5880

\begin{abstract}
Sable were studied in the Rhodes Matopos National Park in Zimbabwe from 1971-1978. This paper discusses aspects of body growth, both isometric and allometric, from the study. Also, age determination of the species from field observation, macroscopic analysis and microscopic examination of various tissues. Much of the data were taken from free-living and semi free-living known-age animals.
\end{abstract}

\section{A. Growth}

\section{Introduction}

Little has been published on growth rates of large wild animals because of difficulties involved in measuring and determining the mass of representative samples, and limitations of existing ageing techniques. In a detailed study on the population dynamics of sable Hippotragus niger in Zimbabwe (Grobler 1978), the growth of the species was looked at as a basis for investigating methods of age determination.

There are two important quantitative aspects of growth studies (Hanks 1972). The first is concerned with changes in mass, height and length of the whole animal or parts of the animal with age (isometric growth). The second aspect is termed allometric growth, the term "allometry" being accepted to mean a change of proportions (whether morphological or chemical) with increase in size (Reeve \& Huxley 1945). Both aspects were studied in respect of sable from the main study area which was in the Rhodes Matopos National Park (RMNP), some $48 \mathrm{~km}$ south west of Bulawayo in Zimbabwe.

Data for the growth study and subsequent age determination were obtained from 48 newborn calves (marked and released in the study area 
from 1971-1973 (Grobler 1974), eight semi free-ranging captive animals and material collected in the field during the period 1970-1978. Nine freeranging known-age sable were collected in February 1977 and two were immobilised for examination when they were 46 months old. The semi free-ranging sable were measured and their mass determined first at weekly intervals until 19 months old, then on a monthly basis until the measurements had reached the asymptotes.

To standardise the presentation of growth data, the formula for growth in mass and basic equation of Von Bertalanffy (1938) was used as in Hanks (1972). The formula derived by Beverton \& Holt (1957) for growth in weight was:

$\mathrm{wt}=\mathrm{W}_{\infty}\left(1-\mathrm{e}^{-\mathrm{k}(\mathrm{t}-\mathrm{to})}\right)^{3}$

where $w t=$ weight at age $t$.

$\mathrm{W}=$ asymptotic weight.

$\mathrm{k}=$ coefficient of catabolism of body materials per unit weitht and time.

$\mathrm{t}=$ age of the animal.

to $=$ theoretical age at which the animal would have zero weight with the same growth pattern as that observed in later life.

For growth in height the formula used here was:

$\mathrm{ht}=\mathrm{H}_{\infty}\left(1-\mathrm{e}^{-\mathrm{k}(\mathrm{t}-\mathrm{to})}\right)$

Results

\section{Isometric growth}

Mean body measurements for sable in the Matopos (RMNP) in relation to age are shown in Table 1. It was evident that most parameters had reached the asymptote within 36 months in both males and females. Body measurements of free-living known-age sable are shown in Table 2. The details of body growth in the semi free-ranging sable are presented in Grobler (1978), these data demonstrated the variability as reflected by individual growth rates as well as actual growth rates of individuals. The combined data were, however, too small to reflect the mean growth rate of the population and the theoretical growth curves calculated were of limited value.

Good fits were obtained for growth in ear length of females (Fig. 1) and satisfactory fits for growth in wither height for both males and females (Fig. 2). The raw data were plotted for increase in body mass with age (Fig. 3). The data on horn growth were directly applicable to detailed age determination techniques and as such are presented in the relevant section below. 
Table 1

Mean body measurements of sable from the Matopos, Zimbabwe

a. MALES

\begin{tabular}{crlllllll}
\hline Age in months & & Tl & Hf & h & E & With & Mass $(\mathrm{kg})$ & $\mathrm{n}$ \\
\hline \multirow{2}{*}{$0-1$} & $\overline{\mathrm{X}}$ & 199 & 328 & 54 & 133 & 71 & 19,6 & 15 \\
& $\mathrm{SEX}$ & 6,1 & 5,6 & 0,6 & 2,8 & 0,9 & 0,9 & - \\
\multirow{2}{*}{6} & $\mathrm{X}$ & 307 & 410 & 75 & 180 & 95 & 67,3 & 3 \\
& $\mathrm{SEX}$ & 18,5 & 0 & 0 & 2,9 & 2,0 & 3,3 & - \\
\multirow{2}{*}{12} & $\mathrm{X}$ & 328 & 418 & 85 & 193 & 102 & 94,0 & 3 \\
& $\mathrm{SEX}$ & 11,7 & 3,3 & 2,9 & 3,4 & 3,4 & 3,1 & - \\
\multirow{2}{*}{18} & $\mathrm{X}$ & 342 & 431 & 87 & 200 & 104 & 108,0 & 2 \\
& $\mathrm{SEX}$ & 12,5 & 1,0 & 2,5 & 0 & 1,5 & 6,5 & - \\
24 & $\mathrm{X}$ & 390 & 430 & 90 & 205 & 115 & 204,0 & 3 \\
& $\mathrm{SEX}$ & 30,6 & 3,5 & 0,7 & 5,0 & 0,8 & 8,2 & - \\
& $\mathrm{X}$ & 421 & 435 & 88 & 216 & 114 & $203(\mathrm{n}=10)$ & 20 \\
& $\mathrm{SEX}$ & 10,1 & 8,23 & 1,34 & 3,8 & 2,0 & 2,7 & - \\
\hline
\end{tabular}

b. FEMALES

\begin{tabular}{|c|c|c|c|c|c|c|c|c|}
\hline Age in months & & $\mathrm{T} 1$ & $\mathrm{Hf}$ & $\mathrm{h}$ & $\mathrm{E}$ & With & Mass(kg) & $\mathrm{n}$ \\
\hline \multirow[t]{2}{*}{$0-1$} & $\overline{\mathrm{X}}$ & 202 & 320 & 54 & 133 & 71 & 19,6 & 23 \\
\hline & SEX & 3,8 & 4,3 & 0,5 & 1,5 & 0,4 & 0,8 & - \\
\hline \multirow[t]{2}{*}{6} & $\overline{\mathrm{X}}$ & 303 & 402 & 74 & 185 & 94 & 65,2 & 4 \\
\hline & SEX̃ & 5,7 & 3,1 & 2,5 & 2,4 & 0,8 & 3,8 & - \\
\hline \multirow[t]{2}{*}{12} & $\overline{\mathrm{X}}$ & 326 & 415 & 87 & 197 & 102 & 93,3 & 3 \\
\hline & SEX & 1,6 & 2,9 & 1,7 & 3,3 & 0,7 & 1,6 & - \\
\hline \multirow[t]{2}{*}{18} & $\overline{\mathrm{X}}$ & 335 & 420 & - & 205 & 103 & 110,7 & 2 \\
\hline & SEX & 5,0 & 0 & - & 5,0 & 0,4 & 2,5 & - \\
\hline \multirow[t]{2}{*}{24} & $\overline{\mathrm{X}}$ & 371 & 429 & 80 & 210 & - & 136,7 & 4 \\
\hline & SEX̄ & 14,7 & 12,6 & 2,3 & 9,2 & - & 2,5 & - \\
\hline \multirow[t]{2}{*}{+36} & $\overline{\mathrm{X}}$ & 393 & 418 & 85 & 195 & 112 & $164(n=5)$ & 22 \\
\hline & SEX & 3,4 & 5,6 & 1,5 & 3,3 & 0,6 & 2,4 & - \\
\hline
\end{tabular}

$\mathrm{Tl}=$ tail length $\mathrm{mm}, \mathrm{Hf}=$ hind foot length $\mathrm{mm}, \mathrm{h}=$ hoof length $\mathrm{mm}, \mathrm{E}=$ ear length $\mathrm{mm}$, With= wither height $\mathrm{cm} . \mathrm{SEX}=$ standard error of the mean.

\section{Allometric growth}

Because body mass reflects body condition and reached the asymptote at a later age than other measurements, it was used for correlation with other measurements. Good linear relationships were obtained for hindfoot, tail, ear and hoof length with increase in body mass, up to the age of 19 months (Fig. 4). Wither height up to 49 months old and body girth in the 21-49 month old animals measured, correlated well with body mass (Fig.5). Body girth in females is influenced by pregnancy, two females gained $25 \mathrm{~kg}$ in body mass during the last six weeks in pregnancy with a 75 
Table 2

Body measurements obtained from konw-age free-living sable in the Matopos, Zimbabwe

\begin{tabular}{lllllllllll} 
Ref. & Sex & $\begin{array}{l}\text { Age } \\
\text { (mths) }\end{array}$ & E & Tl & BC & T & Hf & h & With & $\begin{array}{l}\text { Mass } \\
(\mathrm{kg})\end{array}$ \\
\hline "Susy" & F & 6 & 178 & 292 & - & - & 381 & 63 & - & - \\
R6 & F & 46 & 200 & 350 & - & 143 & 370 & 75 & - & - \\
R11 & F & 60 & 198 & 360 & 220 & 217 & 403 & 95 & 110 & 157 \\
R12 & F & 60 & 179 & 395 & 215 & 214 & 427 & 77 & 114 & 169 \\
R4 & F & 72 & 210 & 380 & 221 & 214 & 400 & 98 & 110 & 166 \\
& & & & & & & & & & \\
Y1 & M & 46 & 210 & 410 & - & 170 & 360 & 90 & - & - \\
Y23 & M & 48 & 200 & 410 & 226 & 222 & 420 & 90 & 114 & 189 \\
Y11 & M & 60 & 211 & 410 & 229 & 211 & 430 & 82 & 115 & 171 \\
Y7 & M & 64 & 222 & 421 & 216 & 222 & 428 & 100 & - & - \\
Y3 & M & 72 & 220 & 410 & 229 & 220 & 410 & 95 & 115 & 196 \\
\hline
\end{tabular}

$\mathrm{E}=$ ear $\mathrm{mm}, \mathrm{Tl}=$ tail length $\mathrm{mm}, \mathrm{BC}=$ body curve $\mathrm{cm}, \mathrm{T}=$ total length $\mathrm{cm}, \mathrm{Hf}=$ hind foot length $\mathrm{mm}, \mathrm{h}=$ hoof length $\mathrm{mm}$, with=wither height $\mathrm{cm}$

$\mathrm{mm}$ and $100 \mathrm{~mm}$ gain in stomach circumference and only $20 \mathrm{~mm}$ and 15 $\mathrm{mm}$ respective gain in chest girth. Large ranges in mass in adults may also influence predictions from body girth. Two partly free-ranging females 40 months old, under the same range conditions and of almost equal body size, had a mass difference of $40 \mathrm{~kg}$.

Adult females in really poor physical condition had a mass of 130-140 $\mathrm{kg}$, those in average to good condition $160-180 \mathrm{~kg}$ and those in very good condition or heavily pregnant were $180-200 \mathrm{~kg}$. Adult males in the study area in poor condition were less than $160 \mathrm{~kg}$, those in moderate condition $160-180 \mathrm{~kg}$, those in good condition $180-200 \mathrm{~kg}$ and those in very good condition up to $230 \mathrm{~kg}$.

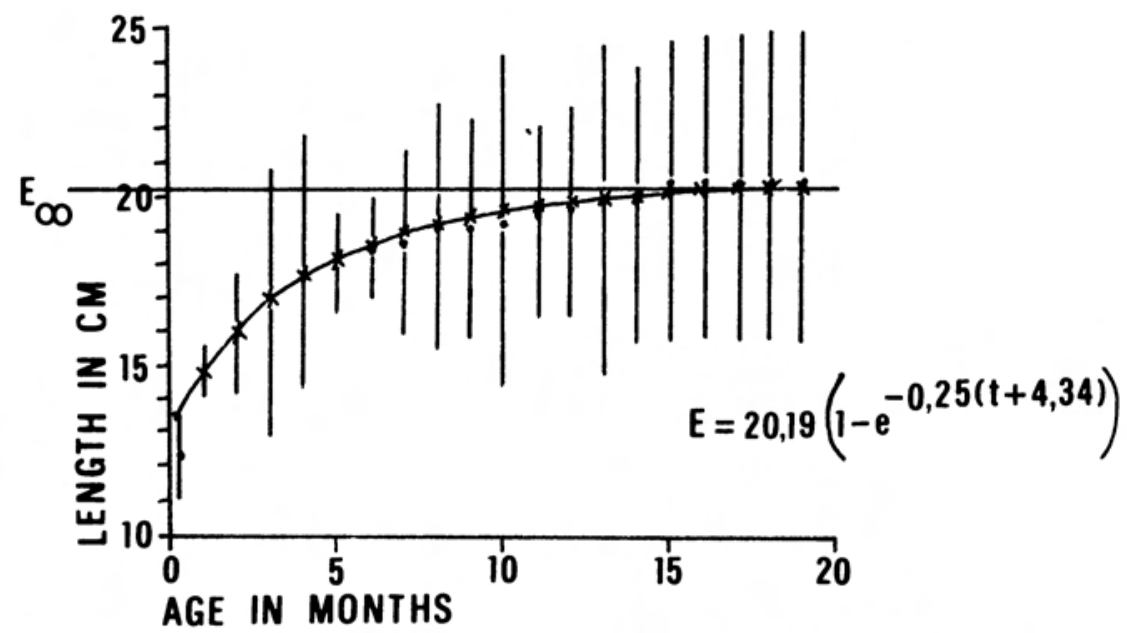

Fig. 1. Increase in ear length in relation to age, of semi free-ranging known-age female sable in the Matopos, Zimbabwe. 


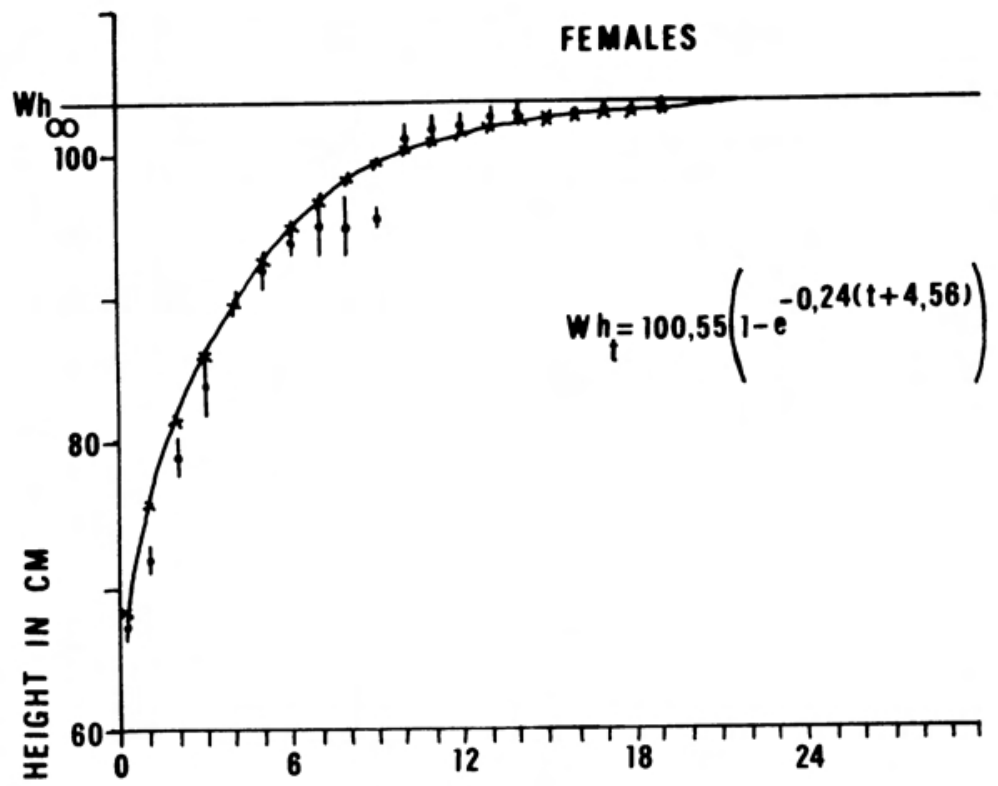

AGE IN MONTHS

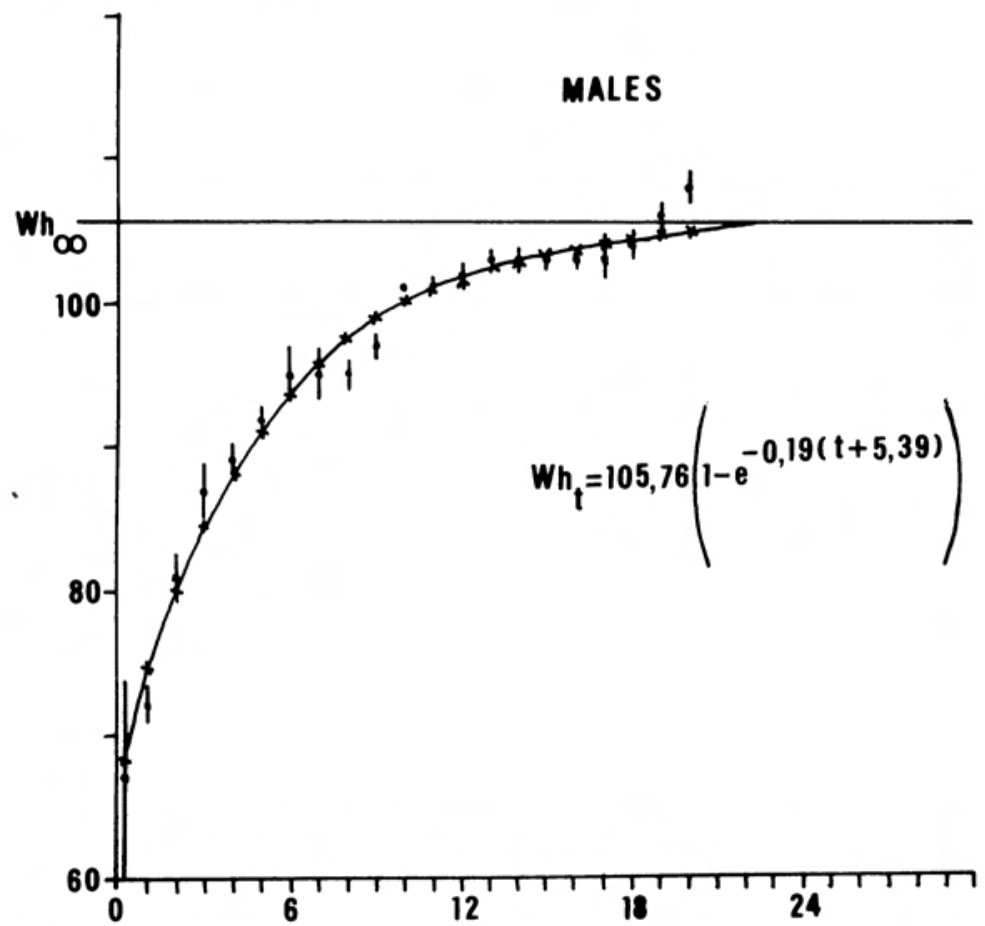

\section{AGE IN MONTHS}

Fig. 2. Growth in wither height in relation to age of semi free-ranging knownage sable in the Matopos, Zimbabwe. 


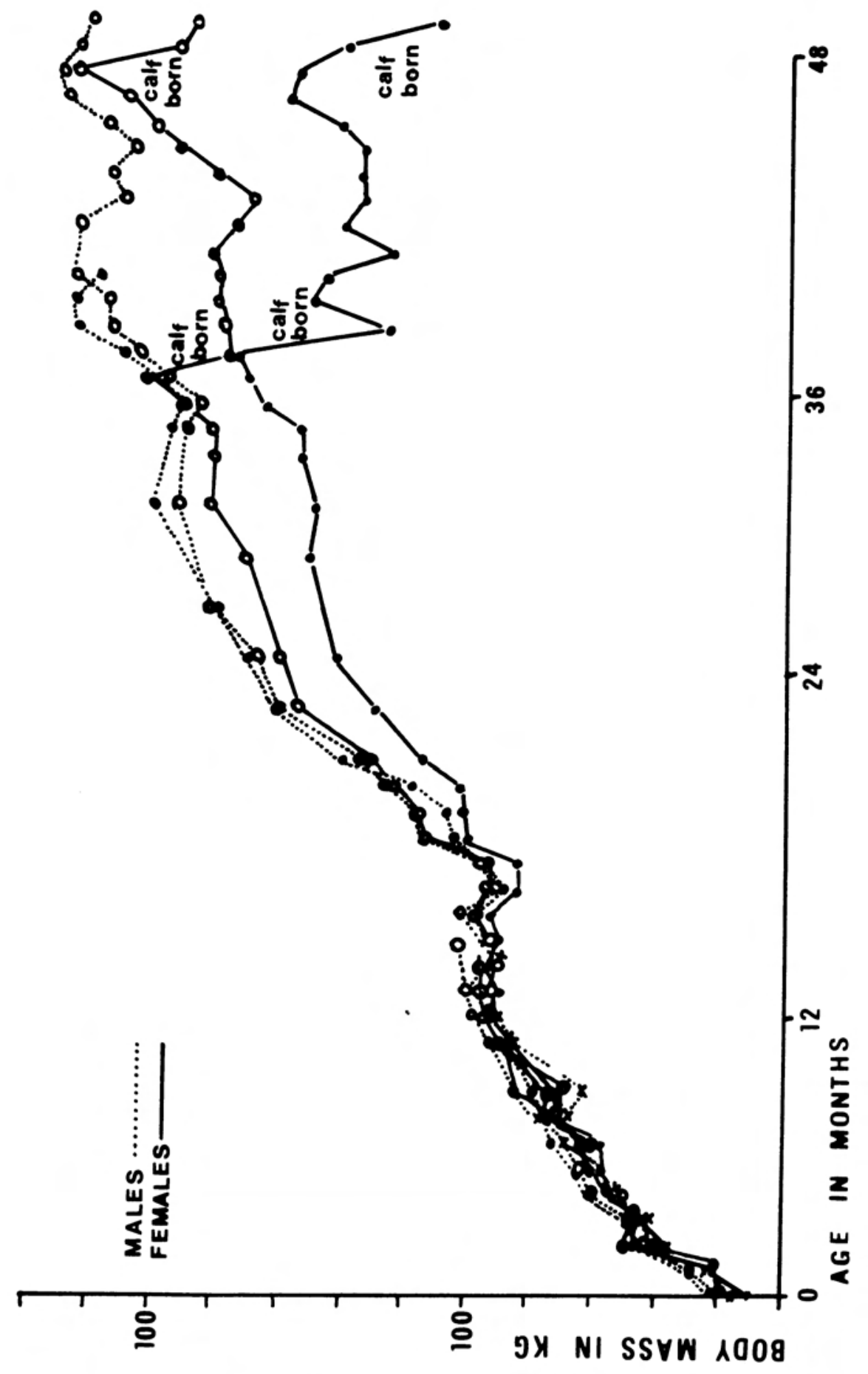

Fig. 3. Increase in body mass of individual partly free-ranging known-age sable in the Matopos, Zimbabwe. 

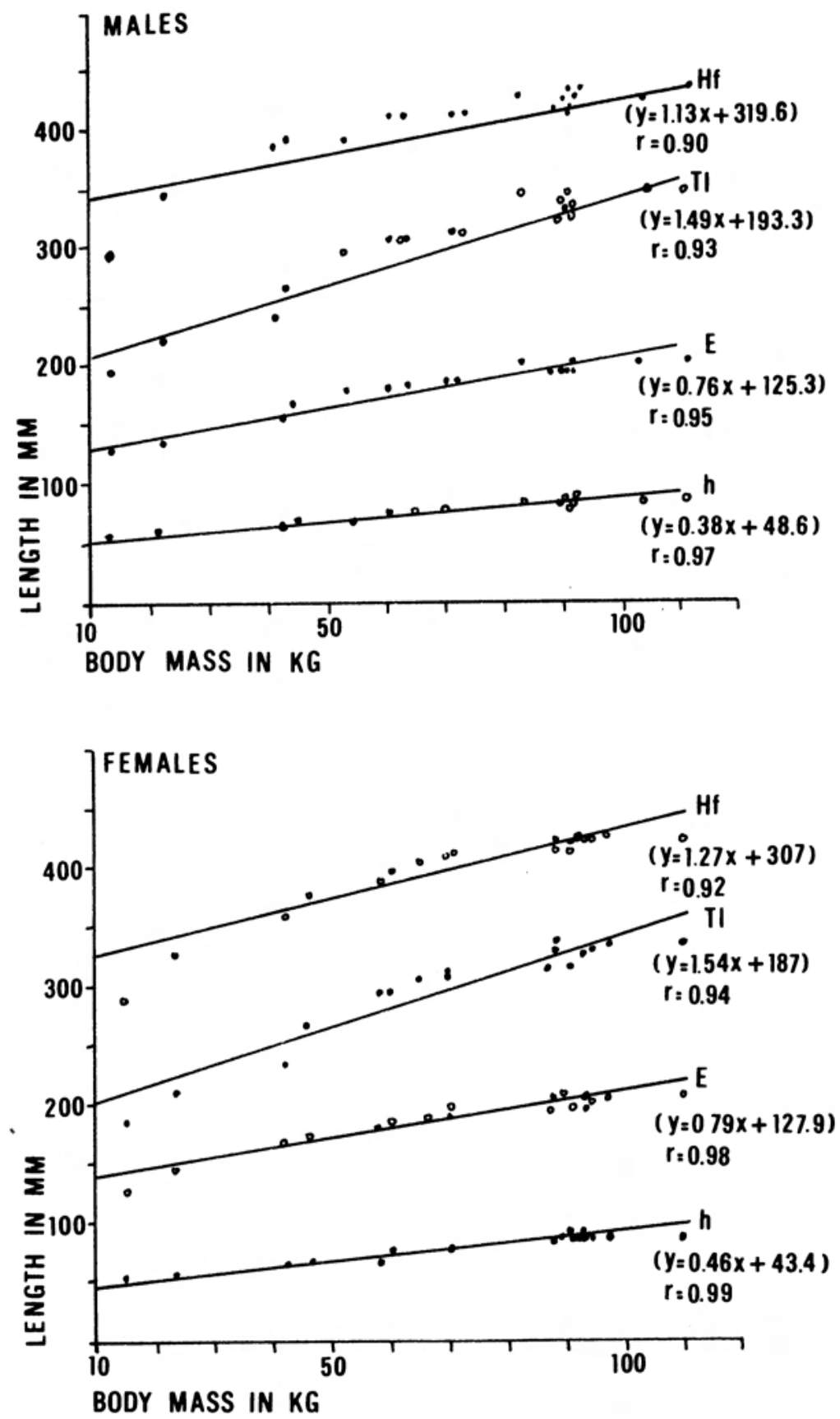

Fig. 4. Increase in body measurements in relation to increase in body mass of partly free-ranging known-age sable up to 19 months old, Matopos, Zimbabwe.

$(\mathrm{Hf}=$ hind foot length; $\mathrm{Tl}=$ tail length; $\mathrm{E}=$ ear length; $\mathrm{h}=$ hoof length). 

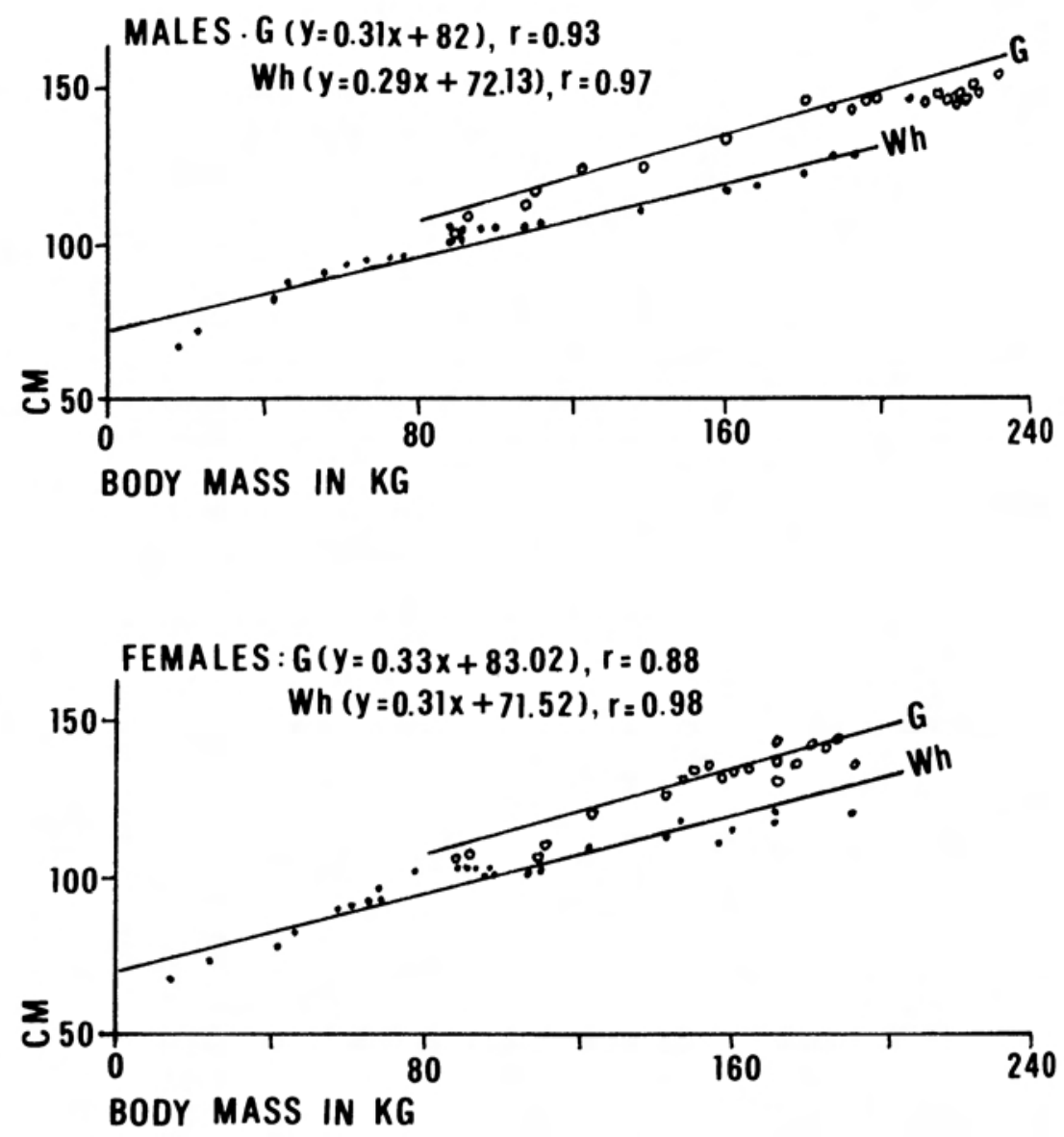

Fig. 5. Relationships between body girth $(\mathrm{G})$ and wither height (Wh) and body mass of semi free-ranging known-age sable up to 49 months old, Matopos, Zimbabwe.

\section{Discussion}

Factors influencing growth were not isolated as the objective was to asses growth patterns as a basis for age determination. It was evident that sable may reach sexual maturity before physical maturity. Females conceived at about 27 months old but were only physically mature at five to six years old. Males were sexually mature at about 36 months old and only reached physical maturity at seven to eight years old. The organs which showed the greatest potential for age determination were the horns as these continued to grow and change shape throughout the life of a sable.

Growth was not a uniform process but continued, influenced by food quality and availability, in a fairly erratic pattern which caused growth 
checks measureable in certain growing tissues. Social and nutritional stress would influence the pattern of growth further and assist in the formation of seasonal incremental lines in certain tissues. These were the lines that were looked for when investigating age determination techniques.

\section{B. Age determination}

\section{Introduction}

Accurate age determination is an essential pre-requisite for the understanding of many aspects of animal biology, since without this data one cannot determine the uniformity of comparable data or age variation. The more widely used methods are reviewed by Morris (1972) and these were used on a broad basis in the present study.

The precise developmental status, i.e. the degree of maturity which was attained was an important consideration. This can be estimated in several ways and expressed as an age, namely, (a) skeletal age, (b) dental age, (c) morphological age, and (d) secondary sex characteristics (Steenkamp 1975). The emphasis in the present study was on dental and morphological age, looked at in terms of field observation, macroscopic material in hand, microscopic material in hand, and microscopic techniques.

Free-living and partly free-ranging known-age sable were observed and examined over a period of eight years, and 16 skulls from known-age sable up to 72 months old were examined and used as a basis for age determination. This was augmented with data from other material which became available.

\section{Dentition}

\section{Eruption and replacement}

Eruption and replacement of deciduous teeth (incisors, canines, premolars) and eruption of permanent teeth (molars), were recorded against age for upper jaws (maxillae) and lower jaws (mandibulae). Mandibles were also sectioned longitudinally with a thin hacksaw blade to determine the postion of the teeth before eruption.

(a) Mandible. The sable is born with the incisors, canines and premolars erupted. The last of these to erupt are the $I_{2}$ which were found to be in the process of erupting in four newborn calves $(n=48)$ and one full term foetus $(n=1)$. The deciduous teeth only reach their maximum 
crown height at about 30 days. Initially the incisors and canines are used with the tongue to hold the nipple while suckling and the two first incisors form a distinct $\mathrm{V}$-shape which must assist in this practice.

The first permanent tooth to erupt is $\mathrm{M}_{1}$. This takes place from 6-10 months old. A longitudinal section of the mandible showed the molars lying one behind the other and developing to erupt with the increase in jaw length (Fig. 6). In logical sequence $\mathrm{M}_{2}$ and $\mathrm{M}_{3}$ erupted next at 10-14 months and 14-18 months respectively.

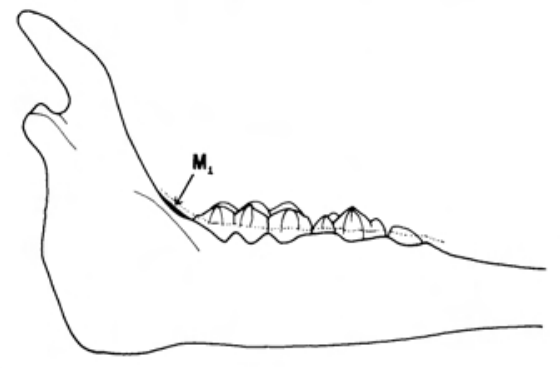

A
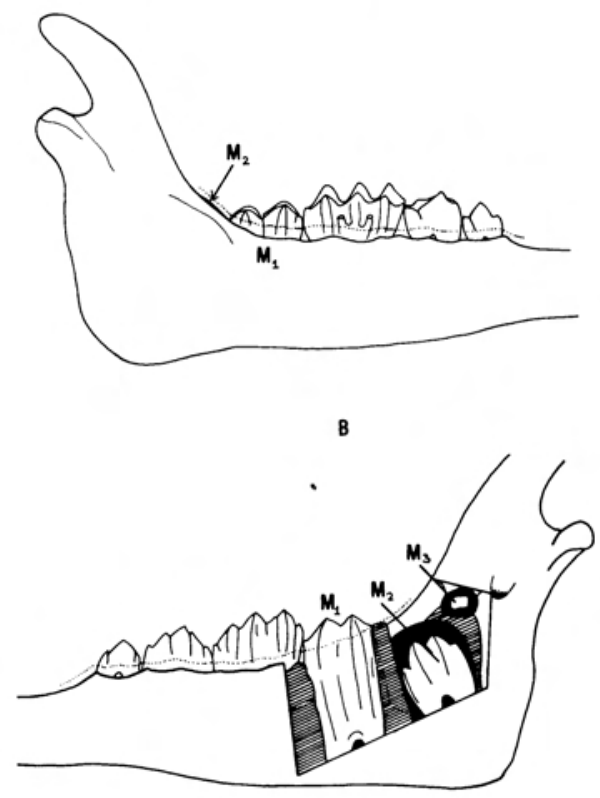

C

Fig. 6. Sable mandible showing:

A. Full deciduous dentition in premolars and position of molar one (M1) before eruption (lingual plane). B. M1 erupting and position of M2 before eruption (lingual plane). C. Positions of M1, M2 and M3, in section. (The limits of the gum is shown by the dotted line). 
By the time the molars have erupted, changes have taken place in the labial area of the mandible. Because of limitations in space, the permanent incisors and canines develop in such a way as to erupt on a rotational plane, twisting as they grow to replace the well worn deciduous teeth. This can best be presented in diagramatic form once the teeth have been exposed by sectioning the area from different sides (Fig. 7). The arrows indicate the direction of twist on the axis and the direction in which the teeth grow to erupt.
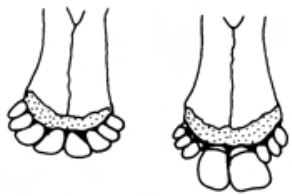

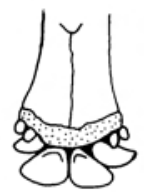

c

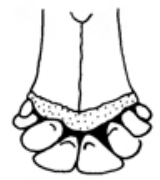

d

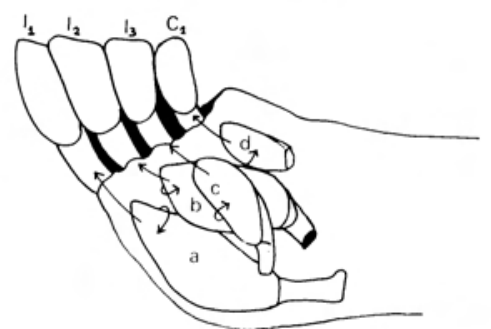

A

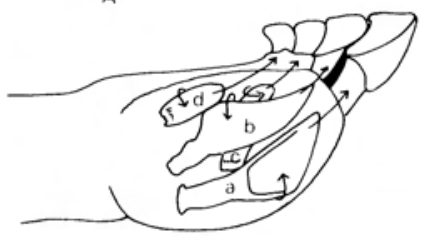

B

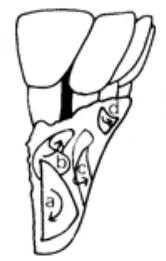

C

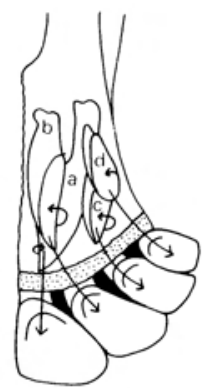

D

Fig. 7. Sable mandibles showing: 1. (Top row). Sequence of replacement of deciduous incisors $(\mathrm{a}=$ all deciduous $), \mathrm{b}=\mathrm{I} 1$ replaced, $\mathrm{c}=\mathrm{I} 2$ replaced, $\mathrm{d}=\mathrm{I} 3$ replaced). 2. Positioning and movement involved in erupting incisors and canines as seen in section. $\mathrm{A}=$ lingual plane $\mathrm{B}=$ buccal, $\mathrm{C}$ = labial, $\mathrm{D}=$ occlusal. $(\mathrm{a}=\mathrm{I} 1, \mathrm{~b}=\mathrm{I} 2, \mathrm{c}=\mathrm{I} 3, \mathrm{~d}=\mathrm{C} 1)$. 
The sequence of eruption on both sides of the mandible is synchronised. First to erupt (Fig. 8 (a-d)) is $I_{1}$ (18-24 months old), followed by $\mathrm{I}_{2}$ (22-28 months), $\mathrm{I}_{3}$ (28-34 months) and $\mathrm{C}_{1}$ (34-40 months). The eruption of the permanent premolars generally starts towards the end of this phase at about 34-42 months old. There is no set sequence of eruption although $\mathrm{Pm}_{3}$ is generally a little more advanced than $\mathrm{Pm}_{2}$ and $\mathrm{Pm}_{4}$.

At the age of 44 months the sable had a full set of permanent teeth in the mandibles. There was no apparent difference between males and females although individual variation did exist.

(b) Maxilla. At birth the deciduous premolars are all erupted and grow to their maximum size after about 30 days. As in the mandible, the molars erupt in sequence and develop one behind the other (Fig. 9). The $\mathrm{M}^{1}$ erupts at $6-13$ months, $\mathrm{M}^{2}$ at $10-15$ months and $\mathrm{M}^{3}$ at $14-19$ months. The premolars follow the same sequence as in mandibles and eruption takes place between 16 and 24 months.

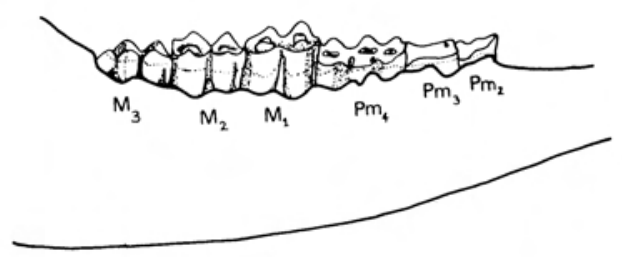

(a)
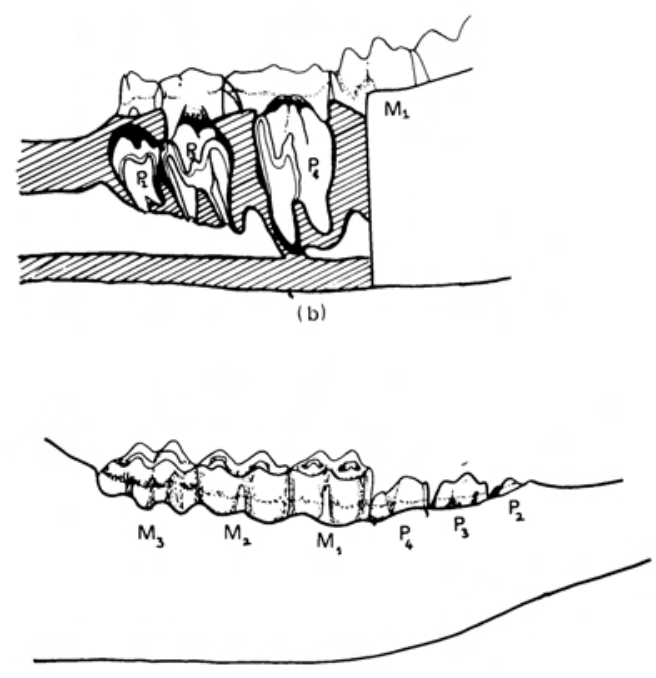

(c)

Fig. 8. Sable mandible showing: (a) degree of attrition on deciduous premolars immediately before replacement (lingual plane) (b) buccal view of (a) in section showing position of erupting premolars (c) newly erupted premolars and relative size of molars (lingual plane). 

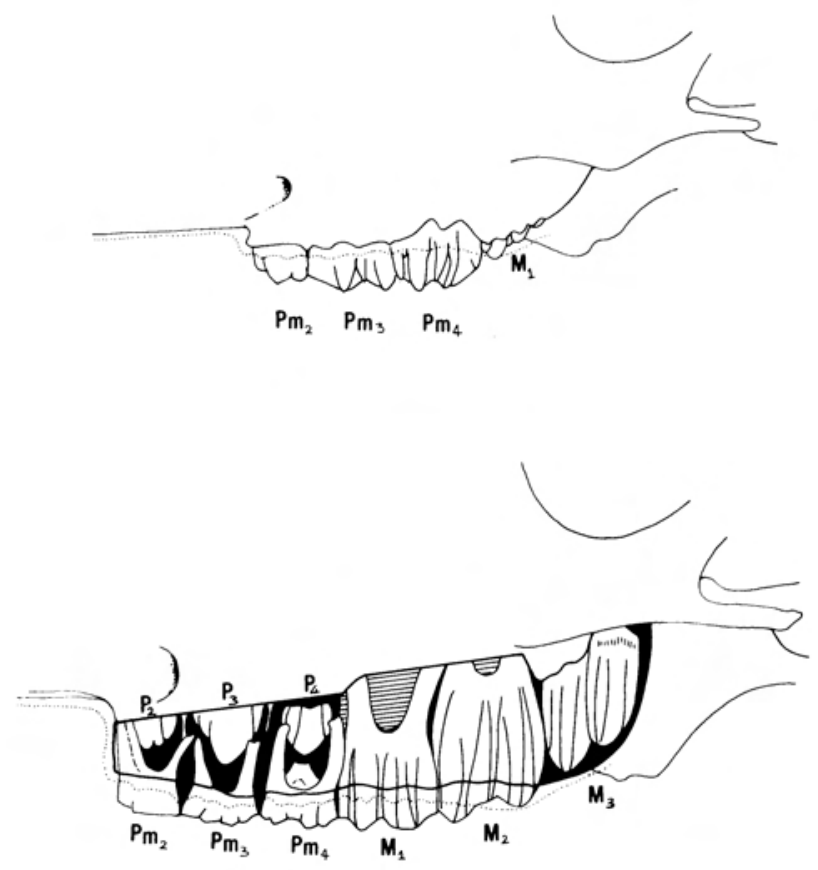

B

Fig. 9. Sable maxilla showing: A. Deciduous premolars and erupting molar one (lingual plane). B. Position of erupting premolars ( $\mathrm{P} 2$ to $\mathrm{P} 4)$ in relation to deciduous (Pm2 to Pm4) and molars (M1 to M3) as in section on a lingual plane.

\section{Attrition patterns}

As sable grow older, attrition patterns form on the occlusal surfaces of the premolars and molars due to the changing shapes of the infandibulae as the teeth are worn with age. The incisors and canines also wear with age although no patterns develop on them.

Seven annual age classes were established for sable over 44 months old for both the mandibles and the maxillae (Figs. 10 and 11). In four skulls examined $(n=90)$ the age class pattern on the maxillae did not correspond with that of the mandible. It was evident that although patterns formed on the teeth with increase in age, the age classes from these could not be used in isolation to determine absolute age.

Reabsorbtion of the incisor and canine roots takes place in a similar manner as that described by Spinage (1967) for Defassa waterbuck. The teeth are eventually cut off at the level of the gum by the action of the 

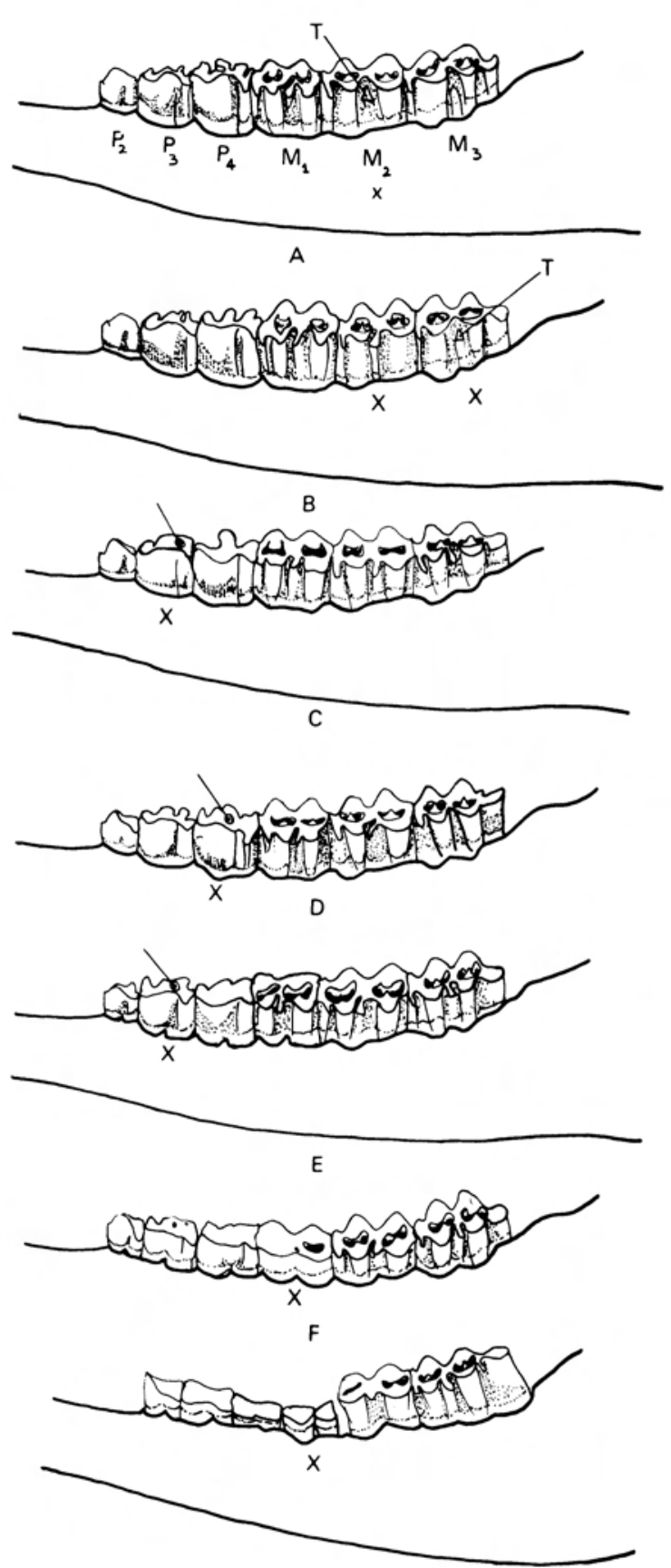

G

Fig. 10. Attrition patterns on the occlusal surface of premolars of Matopos sable mandibles as a guide to age determination. (Views from lingual side). (A to $\mathrm{F}$ are annual age classes from 4 to 9 years old, $\mathrm{G}=10$ years and older. $\mathrm{X}=$ tooth with diagnostic pattern, $\mathrm{T}=$ Triangle). 


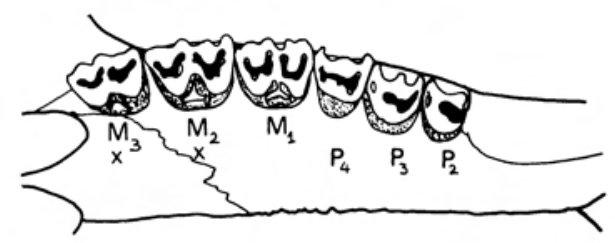

A

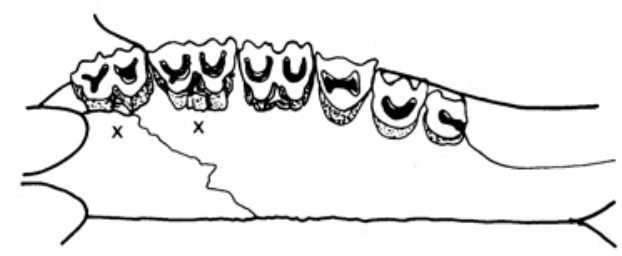

B

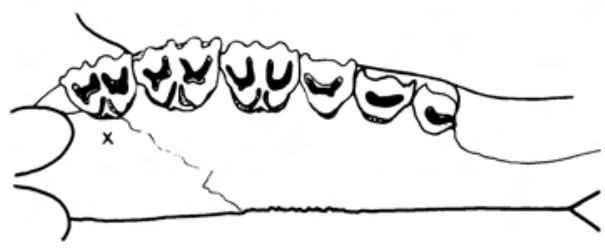

C

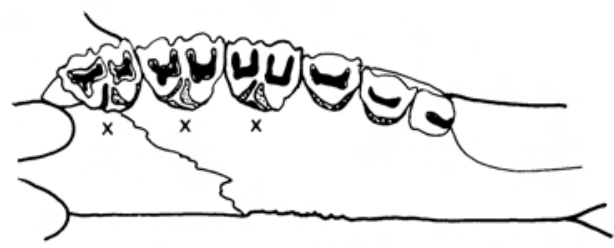

D

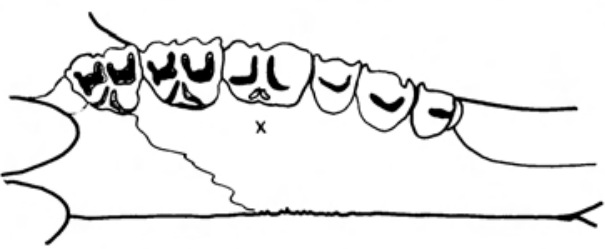

E

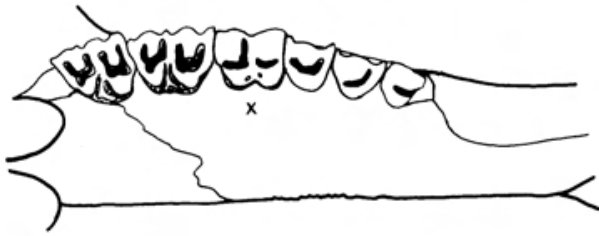

$\mathbf{F}$

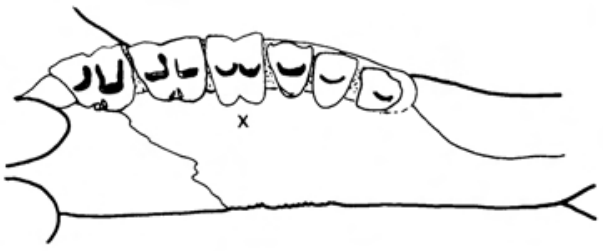

G

Fig. 11. Attrition patterns on the occlusal surface of upper premolars and molars of Matopos sable as a guide to age determination. (A to $\mathrm{F}$ are annual age classes from 4 to 9 years old, $\mathrm{G}=10$ years and older. $\mathrm{X}=$ tooth with diagnostic pattern). 
grass sliding between the teeth through the thinning enamel. In the over 10 year olds (Class G) most of the incisors and canines are "capped".

Mandibles and maxillae of sable from other parts of Zimbabwe had the same pattern of wear, but data were not adequate to indicate different rates of wear in different areas. Tooth wear may be influenced by the quantity of mineral matter in plant tissue (Baker, Jones \& Wardrop 1959). There is also the possibility of genetic influence on the abrasive and micro-hardness of enamel to consider (see Steenkamp 1969) and such factors may need investigating in different sable populations before applying the method of ageing by attrition patterns.

To quantify teeth wear, crown heights of 2700 teeth were measured, using a caliper and measuring on the buccal side from the gum line vertically to the apex. Differential wear on two sides of the same jaw necessitated measuring both sides and using the mean crown height for each tooth. This was caused by a jaw deformity in two cases and an additional $\mathrm{Pm}^{4}$ on the lingual side of an existing maxillary $\mathrm{Pm}^{4}$. Although the exercise clearly indicated the increase in crown height as the teeth erupted and grew and the decrease in height with age (Table 3), it did not prove an accurate method of determining age. The accuracy of dental wear age estimation in black-tailed deer was found to be accurate for young deer but as the animals grew older (more than five years) the method became less accurate with a tendency to underestimate the ages (Thomas \& Bandy 1975). In the present study, sable less than four years old could be aged accurately from tooth wear and eruption. Using horn sections as a means of testing the accuracy of older age classes the following results were obtained. Four year old sable were all correctly placed and $75 \%$ of five year old animals were correctly placed. In the six to nine year old animals only $60-65 \%$ were correctly placed, with an error of \pm 1 year in the six, seven and eight year olds and an error of \pm 2 years in nine year olds. Over 10 year olds were all correctly placed but this covered a range in age.

\section{Tooth sectioning}

This method is detailed by Klevezal \& Kleinberg (1969). Both dentine and cement in mammalian teeth are characterised by continuous appositional growth around pre-existing tooth material. Tooth formation is recognised by three distinct but overlapping processes, namely matrix formation, mineral apposition and maturation. The disturbance of any or all of these processes may be recognised by irregularities in calcification rhythm (matrix), homogeneity of calcification (apposition), and hardness (maturation).

Calcification rhythm may be disturbed by a sudden and/or severe change in level of nutrition which coincides with seasonal change and results in prominent incremental lines. By virtue of their regular occur- 
Table 3

Mean grouped crown height of sable teeth (in mm) from the Matopos, Zimbabwe

\begin{tabular}{crcccccc}
\hline \multicolumn{4}{c}{ MANDIBLE } \\
\hline Age (mths) & $\mathrm{I}_{1}-\mathrm{C}_{1}$ & $\mathrm{Pm}_{2}-\mathrm{Pm}_{4}$ & $\mathrm{M}_{1}-\mathrm{M}_{3}$ & $\overline{\mathrm{X}}$ & $\mathrm{Pm}^{2}-\mathrm{Pm}^{4}$ & $\mathrm{M}^{1}-\mathrm{M}^{3}$ & $\overline{\mathrm{X}}$ \\
\hline $0-4$ & 9,9 & 9,2 & 0 & 6,3 & 9,1 & 0 & 4,6 \\
$4-10$ & 10,0 & 11,1 & 3,1 & 8,1 & 11,9 & 1,8 & 6,9 \\
$8-14$ & 7,3 & 7,8 & 4,5 & 6,5 & 7,1 & 4,9 & 6,0 \\
12,18 & 8,5 & 6,2 & 10,1 & 8,3 & 7,8 & 8,3 & 8,1 \\
$18-34$ & 12,7 & 5,3 & 12,2 & 10,0 & 10,8 & 11,7 & 11,2 \\
$34-38$ & 14,0 & 13,7 & 13,2 & 13,6 & 12,8 & 11,7 & 12,3 \\
\hline \multirow{2}{*}{ Age (yrs) } & $\mathrm{I}_{1}-\mathrm{C}_{1}$ & $\mathrm{Pm}_{2}-\mathrm{Pm}_{4}$ & $\mathrm{M}_{1}-\mathrm{M}_{3}$ & $\overline{\mathrm{X}}$ & $\mathrm{Pm}^{2}-\mathrm{Pm}^{4}$ & $\mathrm{M}^{1}-\mathrm{M}^{3}$ & $\overline{\mathrm{X}}$ \\
\hline 5 & 13,4 & 13,2 & 12,1 & 12,9 & 13,3 & 11,4 & 12,3 \\
6 & 12,2 & 12,2 & 11,6 & 12,0 & 12,6 & 10,7 & 11,7 \\
7 & 11,4 & 12,1 & 11,7 & 11,7 & 11,9 & 11,1 & 11,6 \\
8 & 10,2 & 11,0 & 10,6 & 10,6 & 11,9 & 11,1 & 11,5 \\
9 & 8,9 & 10,1 & 10,2 & 9,7 & 10,3 & 8,9 & 9,6 \\
10 & 5,9 & 9,4 & 9,5 & 8,2 & 8,2 & 8,8 & 8,5 \\
+11 & 3,3 & 6,8 & 8,9 & 6,3 & 8,2 & 8,8 & 8,5 \\
\hline
\end{tabular}

$\mathrm{I}=$ incisor, $\mathrm{C}=$ canine, $\mathrm{Pm}=$ premolar, $\mathrm{M}=$ molar, $\overline{\mathrm{X}}=$ mean

ence the annuli serve as criteria of age (Steenkamp 1975). Environmental effects result in fluctuation in the rate and nature of the formation of dentine covering a layered, rather than homogeneious structure.

Distinct annulation were present in sable teeth, decalcified, sectioned and examined by Hall-Martin (pers. comm.). From the literature it became apparent that the decalcification process and the sectioning, staining and mounting of the teeth was a long involved process which was not always succesful and required certain sophisticated items of equipment. As most of the sable material came from found skulls, teeth collected for examination were often in a state of dehydration and badly cracked. Decalcification with $5 \%$ nitric acid and EDTA (Ethylenediaminetetra-acetic acid) and subsequent sectioning was not succesful.

A method which met with some sucess was to section a tooth $\left(M_{1}\right.$ chosen for ease of extraction and quality of preservation) with a hacksaw, longitudinally through the centre. The cut surface was then ground down using ' 500 ' followed by ' 600 ' wet carborundum crystylon grit until the cut surface was smooth. To increase the polished effect, household Brasso was used before the tooth was examined under a dissecting microscope with good lighting.

The part of the tooth examined was the area between the root and the crown. Here the cementum was found to be at its broadest and showed distinct lines. The maximum number of "broad" lines were counted along the clearest part of the cementum.

Nine of the sections $(n=30)$ had lines so indistinct as to render the 
results meaningless. These were mostly old animals where compaction of the cementum made the lines indistinct. Of the remaining 21, there were 14 which gave exactly the same calculated age as the horn sections, five a year less and two a year more. The two oldest known-age skulls (72 months) were examined and both showed the predicted number of incremental lines.

\section{Horns}

As both sexes possess horns, the continued growth of horns throughout life presented an ideal parameter for absolute age determination. It has been known for a long time that growth of the horny sheath in Bovidae is not continuous but more or less periodic (see Thompson 1917). This could cause the horn sheath to be composed of a series of all but separate rings which may be formed annually and used in ageing. This was suggested as a means of ageing by Hindekoper in 1891 (in Thompson 1917).

Bovids exhibit seasonal fluctuation in horn growth and consequent changes in horn formation (Geist 1966). External growth checks on horns have been found on a variety of wild sheep and goats (Brandborg 1955; Geist 1966; Ogren 1965; Hansen 1965, 1967; Couturier 1961; Caughley 1965). External growth checks and postmature growth (termed secondary growth in this study) were looked at on several African antelopes including sable by Simpson (1971).

Ogilby (1840) states that horns receive their increments at the lower extremity, they continue to grow throughout life, but only at intervals, depending on the season of the year, the age of the individual and the food supply. The outer surface is consequently marked in general with a greater or lesser number of prominent transverse rings or annuli. He only related this to younger age groups but remarks on possible incremental lines in the common cow.

Ogilby (1840) in his monograph on hollow-horned ruminants, made an important observation which later workers have overlooked and that is the exfoliation of the "deciduous" horn. The horn of young animals has a course spongy texture and is thick and blunt in proportion to the length. A permanent horn develops within the deciduous horn and by its gradual growth supports it like a sheath or scabbard. The young horn, once severed from the vessels which formerly supplied it with nutrient, dries up, bursts as a result of the expanding permanent horn and exfoliates in large irregular strips. This phenomenon is recorded for duiker Sylvicapra grimmia, waterbuck Kobus ellipsiprymnus and gemsbok Oryx gazella by O'Gara \& Matson (1975). It also occurs in the steenbok Raphicerus campestris (pers. obs.) and probably most species of hollow horned ruminants.

Based on the pattern of growth it can be postulated that a horn would be made up of what might be described as a series of cones, one fitting in the other. Such a series of stacked cones would be expected to be sep- 
arated by incremental lines. This structure was indicated by Khan (1936) for blackbuck Antilope cervicapra, D'Abreu (1936) and Biddulph (1936) for nilgai Boselaphus tragocamelus.

Horn growth in sable was characterized by three phases, (a) the formation and subsequent exfoliation of the deciduous horn, (b) the rapid growth of the primary permanent horn during which time the bumps on the horn were formed, and (c) the slow postmature or secondary permanent horn growth evident at the base of the horn.

\section{External appearance of sable horns in relation to age}

The growing points of sable horns on newborn calves are small bumps of naked horny tissue, slightly flaky, hidden by course hair. At the age of about two months the soft deciduous horn starts showing above the hair line on the frontal area of the skull. The horn grows rapidly and has an initial smooth and elastic external texture. By eight months old the horn is still less than the ear length and in cross section the deciduous horn tissue has a clear transparent matrix. The initial growth of the primary permanent horn becomes evident on the inner layers at about four months. The primary permanent horn, in contrast, has a dark pigmented appearance.

Between eight and 12 months old the horn length in males and females is equal to or greater than ear length. In most individuals the first primary annulus appears soon after 12 months. Two known-age females $(n=40)$ had two annulations each at 12 months old. Between 12 and 16 months the horn length in males exceedes that of females (Fig. 12).

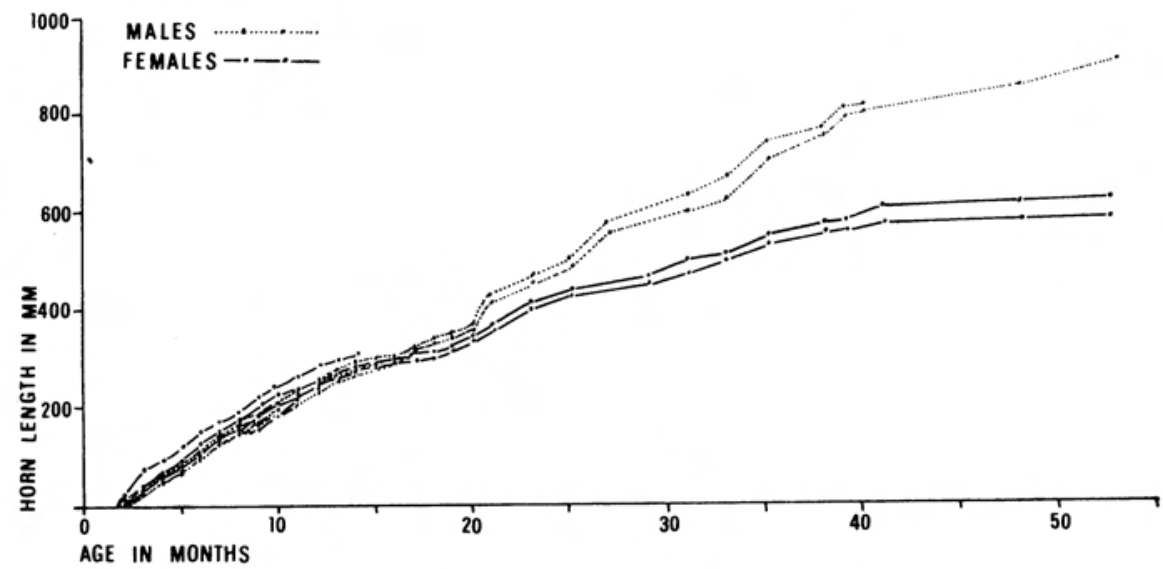

Fig. 12. Growth in horn length of semi free-ranging known-age sable in Matopos, Zimbabwe, in relation to age. 
During the 12-24 month period (yearlings), the primary annulation develops rapidly. The number of annulations in this age group varied from one to 10 , generally less than a third of the horn bearing annulations. It is also during this age that the exfoliation of the deciduous horn takes place. By 16 months old the horns become pale in colour and dry in appearance. The exfoliation commences on the smooth upper part of the horn and peels off to expose the dark primary horn. This takes place rapidly at first and is usually completed by $20-24$ months in age, although the actual annulation flakes of deciduous horn may still be present after this.

The males in the two year age group show distinct curvature towards typical male shaped horns, primary annulation range from 10 to 20 in number and the animal may still be found as part of a breeding group. The female horns are straighter and have the same number of annulations as the males.

During their first two years males are still with the breeding groups. Three year old males start leaving the herd and have horns with a tendency towards full curvature and 20-30 annulations. The females at three years old become difficult to place into annual age classes to anyone not intimately familiar with sable. At four years old the females start showing secondary growth at the base of the horn, generally less than 40 $\mathrm{mm}$ in width.

The males also start showing secondary growth at four years old and look similar to the five year old males. Individual variation in horn shape and length now becomes apparent. With these two age classes the secondary growth rarely exceeds $20 \mathrm{~mm}$ in width and primary annulation exceeds 30 in number. Secondary growth at the base of the horn increases with age (Table 4), until it eventually measures over $80 \mathrm{~mm}$ in animals over 10 years old. The general shape of the horn and amount of secondary growth present can give visual estimations of age.

In very old animals ( 13 years and older) the horn tip becomes worn and eventually starts fracturing. The females become darker with age and old females in the study area were very dark brown to black in colour. The males also become darker with age but more rapidly than the females.

\section{Horn sectioning as a means of determining the age of sable}

Horn sections were cut and prepared as detailed in Grobler (1979). Because the horns were in the form of stacked cones, sections were initially taken all along the horn until the maximum number of incremental lines were found. This was about two thirds of the way up the horn, on the frontal portion of the horn and between the bumps.

Unfortunately no information could be found describing the histology of the horn and this study did not lend itself to a detailed investigation of this aspect. The outer sheath of the horn is basically a modified skin derived structure consisting of hard cornified tissue. Inside this structure lies the 


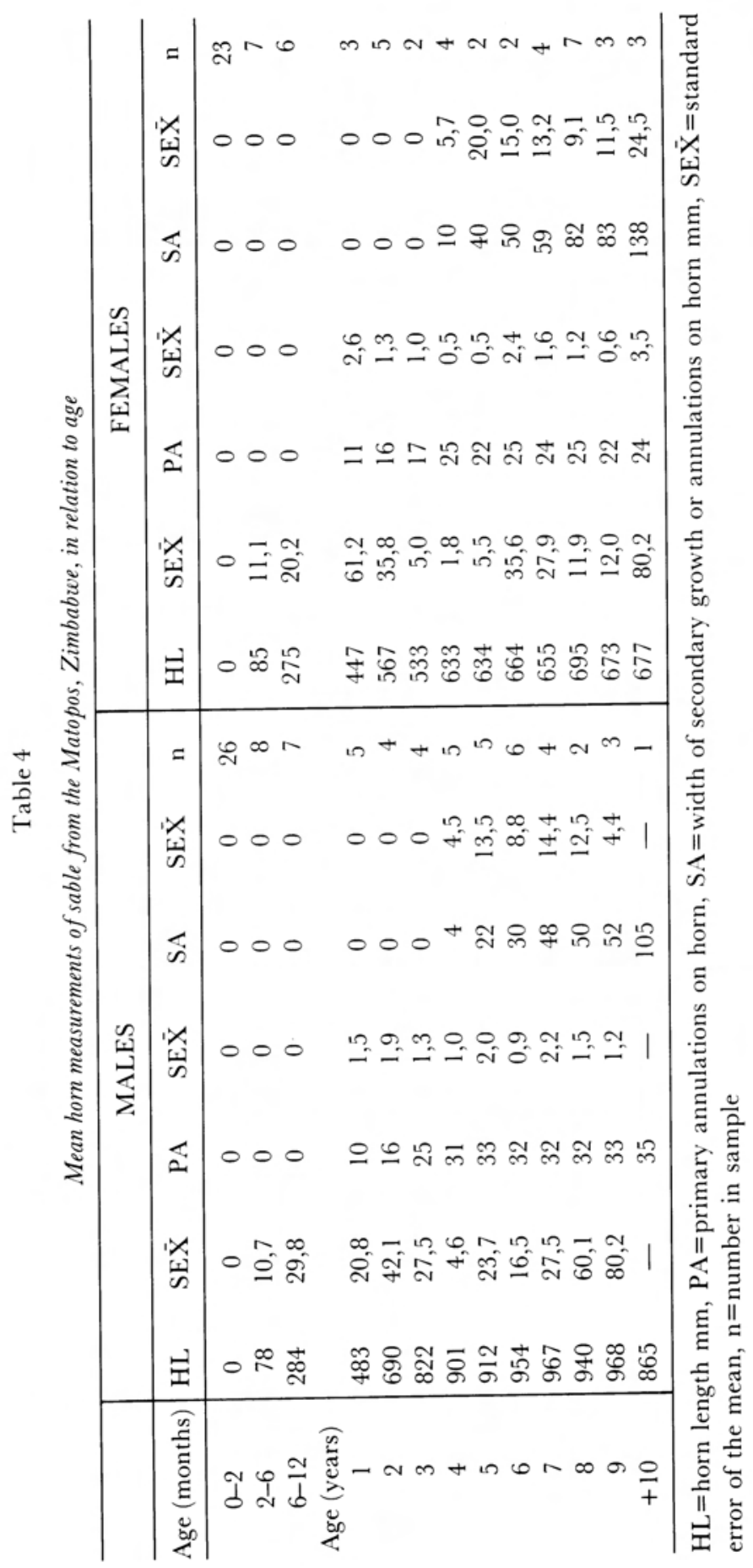


horn core, a bone structure richly supplied with blood vessels and nerves which continue along a central channel to the horn tip. In transverse section the cornified tissue of the torn tip indicates an inner system of interconnecting channels.

The function of this network of channels is not clear but it is suggested that it may serve to keep the horn tissue supple and "alive". With increased growth with age the inner cavity of the horn containing the bone core and vessels becomes blocked off at the upper extremity cutting off the "life-line" to the horn tip. It is at this stage in very old individuals that the horn becomes brittle and commences breaking off in flakes.

The primary growth in section showed relatively broad and distinct growth checks which were confirmed as annual checks from known-age animals collected in the field. The check is presumeably caused by a seasonal nutritional influence during which growth slows down and the tissue becomes compact, concentrating the pigmentation. Other smaller lines appear between these major growth checks, which may be a reflection of various other influences such as calving or a drop in physical condition due to injury or illness.

Growth checks were also present in the secondary growth although it was not always possible to distinguish between secondary and primary. The secondary growth usually had much narrower incremental lines. In some specimens the lines were not as clear as others, this applied particularly to very old animals where tissue compaction was taking place. Of the horn sections looked at $95 \%$ showed clear lines and $5 \%$ were not altogether clear.

This provided a very useful and easy technique for absolute age determination. To determine the age of an adult sable a horn section was cut and the number of lines counted (usually three in primary growth) then one year added to compensate for the loss of the deciduous horn.

\section{Mandible length}

Mandible length has shown some correlation with age in the younger age classes of herbivores (Bergerud 1964; Mitchell 1967; Simpson 1966). Mandible length in sable skulls was measured in a straight line laterally from a point immediately below the incisors to the maximum outer limit at the posterior end of the jaw and was found to increase with age up to three years old but was of limited value.

\section{Hair moult in young sable}

Sable calves are born with reddish fawn-coloured hair covering the body except for the pale underside and pale facial markings. It was noticed that the sable calves underwent a distinct moult pattern up to the 
age of 12 months which could be used to establish approximate birth dates of individuals. This moult pattern was investigated.

The presence of an umbilical cord was looked at during the same investigation but found unreliable. The umbilical cords remained attached for 14-60 days. Hair mounts of moulted and unmoulted parts of the body were examined microscopically. No apparent difference was noticed.

The method was found reliable and as dark hair replaced the brown juvenile hair a set sequence could be followed. This is illustrated in Fig. 13. The same pattern was present at the same time with both wild and semi-free-ranging sable.

\section{Other methods investigated}

As the hooves resembled the horns in texture and were continuously growing structures, these were sectioned in the same manner as horns. No

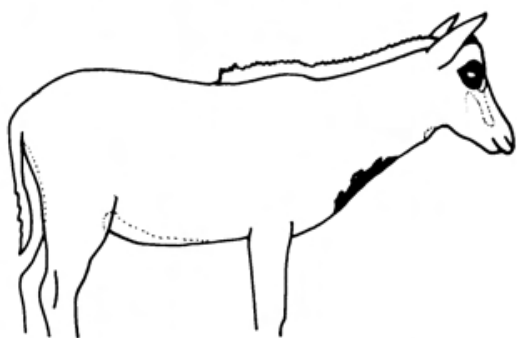

A

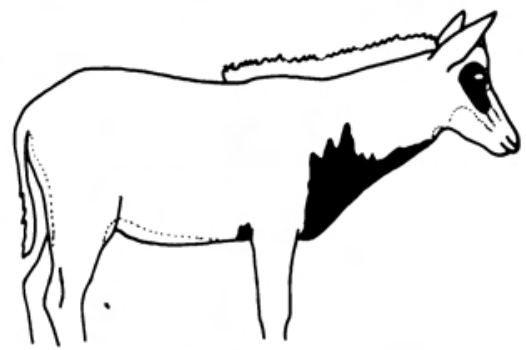

B

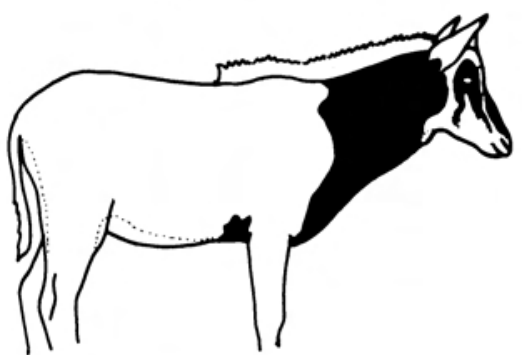

C
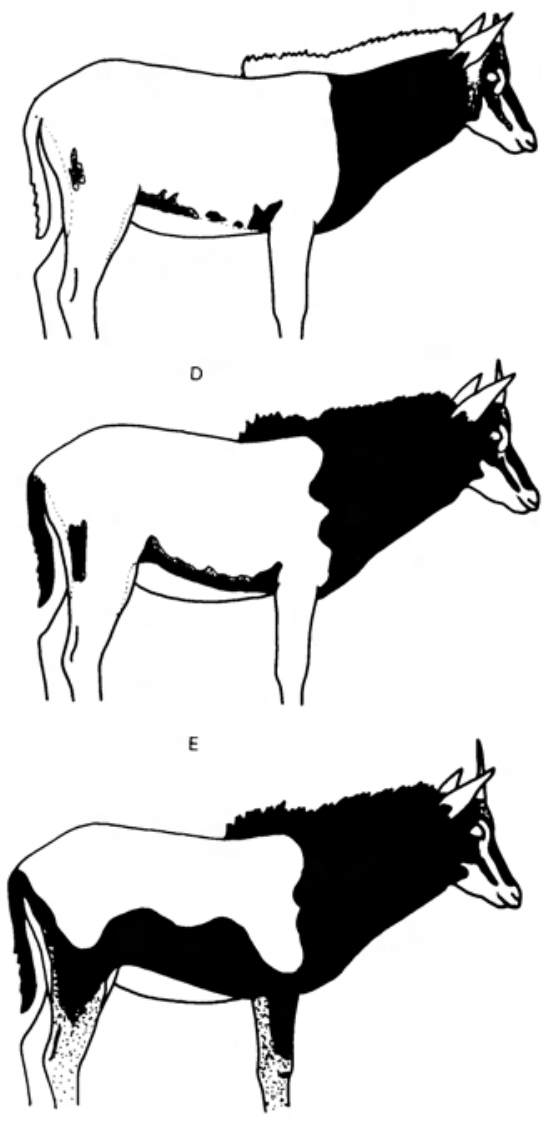

F

Fig. 13. Moult pattern of young sable, in the Matopos, Zimbabwe. Age in months: A (one month) B (2-3) C (4-5) D (6) E (7) F (8-9). 
incremental lines were found and the method was discontinued. Mandibles were also sectioned in the region of the diastema and prepared in the same manner. Again no incremental lines were found.

\section{Discussion}

It is clear that a combination of ageing criteria is necessary to determine the age of sable except when using horn sections. The following combinations are recommended for sable:

(a) Field ageing

(i) Moult pattern (in young animals only).

(ii) Horn shape, length, number of primary annulations, width of secondary growth, condition of horn tips.

(iii) General physical appearance of the animal, bearing in mind that animals in poor condition will look older than they are.

(b) Macroscopic ageing

(i) Horn shape, length, number of primary annuli, width of secondary growth, condition of horn tips.

(ii) Dentition- eruption and replacement, attrition patterns.

(iii) Mandible length in younger animals.

(c) Microscopic ageing

(i) Horn sections.

(ii) Tooth sections.

Field ageing can be assisted by photographing individuals for closer scrutiny. The best technique for ageing in isolation and the only reliable technique found for absolute ageing was horn sectioning.

\section{REFERENCES}

BAKER, G., L. H. P. JONES and I. D. WARDROP. 1959. Causes of wear in sheep's teeth. Nature 184:1583-1584.

BERGERUD, A.T. 1964. Relationship of mandible length to sex in Newfoundland caribou. J. Wildl. Mgmt. 28(1): 54-56.

BEVERTON, R. J. and S. J. HOLT. 1957. On the dynamics of exploited fish populations. Fishery Invest. Lond. Ser. 2 19:1-533.

BIDDULPH, C. H. 1936. Horn growth as observed in blackbuck and nilgai. Journal Bombay Nat. Hist. Soc. 39:171.

BRANDBORG, S.M. 1955. Life history and management of the mountain goat in Idaho. Idaho Dept. Fish \& Game Wildl. Bull. 32:142.

CAUGHLEY, G. 1965. Horn rings and tooth eruption as criteria of in the Himalayan Thar, Hemitragus jemlahicus. New Zeal. J. Sci. 8 (3):333-351.

COUTURIER, M. A. J. 1961. Determination de L'age du bouquetin des alpes (Capra algagras ibex) a l'aide des dents et des cornes. Mammalia 25 (4):453-461. 
D'ARBREU, E. A. 1936. Horn growth as observed in blackbuck and nilgai. Journal Bombay Natural History Society 39:171.

GEIST, V. 1966. Validity of segment counts in ageing bighorn sheep. $J$. Wildl. Mgmt. 30(3):634-635.

GROBLER, J. H. 1974. Aspects of the biology, population ecology and behaviour of the sable Hippotragus niger niger (Harris, 1838) in the Rhodes Matopos National Park, Rhodesia. Arnoldia Rhod. 7(6):1-36.

ĠROBLER, J. H. 1978. Population dynamics of sable in Rhodesia. D. Phil. Thesis, University of Rhodesia.

GROBLER, J. H. 1979. The use of horn sections to determine the age of sable Hippotragus niger. Koedoe 22:219-223.

HANKS, J. 1972. Growth of the African elephant (Loxodonta africana). E. Afr. Wildl. J. 19:251-272.

HANSEN, C. G. 1965. Desert bighorn sheep hunting in Nevada. Frat. Desert Bighorn, Las Vagus. 19 p.

HANSEN, G. G. 1967. The bighorn sheep hunter indoctrination programme. 11:6-12.

KAHN, A. I. 1936. Horn growth as observed in blackbuck and nilgai. Journal Bombay Natural History Society 39:170-171.

KLEVEZAL, G. A. and S. E. KLEINBERG. 1969. Age determination of mammals from annual layers in teeth and bones. Izdatel'stvo Nauka, Moscow, and Israel Prog. for Scientific Translations 1-128.

MITCHELL, B. 1967. Growth layers in dental cementum for determining the age of red deer (Cervus elaphus L.) J. Animal Ecol. 36(2): 279-293.

MORRIS, P. 1972. A review of mammalian age determination methods. Mammal Review 2(3): 69-104.

O'GARA, B. W. and G. MATSON. 1975. Growth and casting of horns by pronghorns and exfoliation of horns by bovides. Journal of Mammalogy 56(4):829-846.

OGILBY, W. 1840. Monograph of the hollow horned ruminants. Transactions of the Zoological Society of London. 33-67.

OGREN, H. A. 1965. The barbary sheep. New Mexico Dep. Game Ë Fish bull. 13:117

REEVE, E. L. R. and J. S. HUXLEY. 1945. Some problems in the study of allometric growth. In: Essays on growth and form. W. E. LE GROS CLARK and P. E. MEDAWAR. (Eds) Oxford: Claredon Press.

SIMPSON, C.D. 1966. Tooth eruption, growth and ageing oriteria in greater kudu (Tragelaphus strepsiceros Pallas.) Arnoldia Rhod. 2(21):1-22.

SIMPSON, C. D. 1971. Horn growth as a potential age criterion in some African ungulates. J. South. Afr. Wildl Manage. Assoc. 1(1): 20-25.

SPINAGE, C. A. 1967. Ageing the Uganda Defassa waterbuck Kobus defassa ugandae Neumann. E. Afr. Wildl. J. 5:1-17.

STEENKAMP, J. D. G. 1969. Effect of brittle hardness and abrasive hardness of enamel on degree of attrition and deciduous teeth from 
representative breeds of Bos indicus and Bos taurus origin. Agroanimalia $1: 23-34$.

STEENKAMP, J. D. G. 1975. Guidelines to the use of dental histology in wildlife research. J. South. Afr. Wildl. Manage. Assoc. 5(2): 89-94.

THOMAS, D. C. and P. J. BANDY. 1975. Accuracy of dental wear age estimates of black-tailed deer. J. Wildl. Mgmt. 39(4): 674-678.

THOMPSON, D. W. 1917. On growth and form. Cambridge: University Press.

VON BERTALANFFY, L. 1938. A quantitative theory of organic growth (inquiries on growth laws II). Human Biology 10(2): 181-213. 